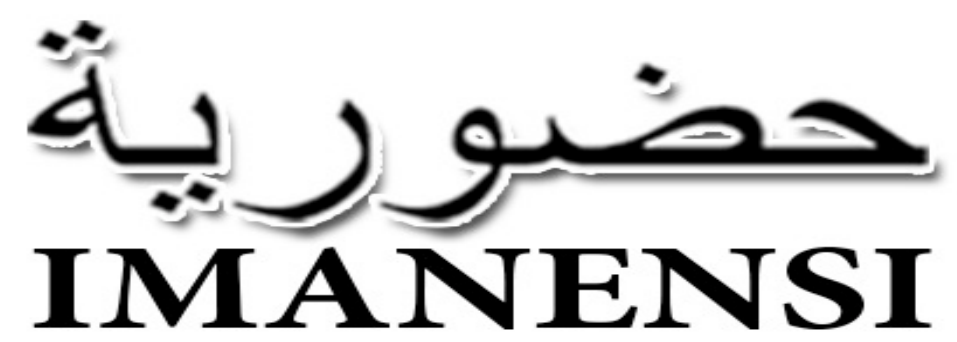

(Jurnal Ekonomi, Manajemen, dan Akuntansi Islam)

Vol 4, No 1, Maret 2019, Hlmn. 61-71

\title{
Memahami kejahatan akuntansi di Indonesia
}

Sudrajat Martadinata, Ahmad Jibrail.

a Universitas Teknologi Sumbawa, J1. Raya Olat Maras Batu Alang Moyo Hulu Sumbawa, Indonesia 84371

1*ajatdinata23@gmail.com.

doi: 10.34202/imanensi.4.1.2019.61-71.

\section{Abstrak}

Tujuan penelitian ini untuk memahami kejahatan akuntansi yang terjadi di Indonesia, menurut mahasiswa program studi akuntansi Universitas Teknologi Sumbawa. Penelitian ini dalam jenis kualitatif dengan pendekatan fenomenologi, melalui beberapa tahapan analisa yakni: noema, epoche, noesis,, intentional analysis, dan eidetic reduction. Kesimpulan dari penelitian ini bahwa di dalam memahami kejahatan akuntansi di Indonesia meurut mahasiswa akuntansi UTS sangat bergantung kepada dua faktor penting: 1) Ilmu akuntansi, 2) Moral manusia.

Kata Kunci: Memahami; kejahatan akuntansi; Indonesia.

\section{Abstract}

The objective of this research was to construe the meaning of accountancy crime that happened in Indonesia, based on the thought of students of accountancy program of Sumbawa University of Technology. The research was qualitative with phenomenology approach, through some steps of analysis; noema, epoche, noesis, intentional analysis and eidetic reduction. The conclusion of this research showed that the mean plethora of accountancy crime cases which happened in Indonesia strongly depends on two important factors: 1) science of accountancy, 2) human's moral.

Keywords: Meaning; Accountancy Crime; Indonesia.

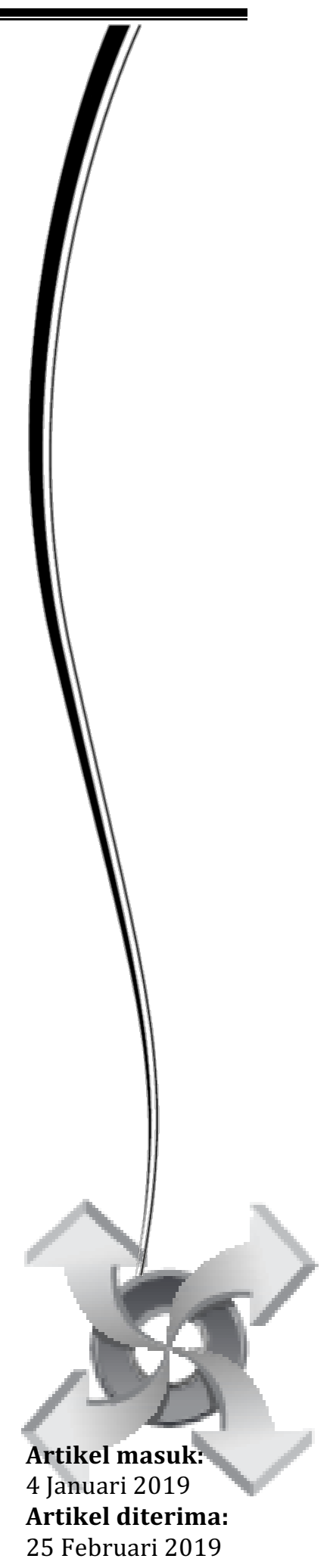


Kejahatan akuntansi merupakan upaya kreatif yang sering dilakukan oleh para akuntan. Upaya kreatif ini dilakukan dengan maksud untuk memunculkan kesan baik atas perusahaan mereka msing-masing. Dari upaya kreatif yang telah membudaya ini, akhirnya lahir istilah akuntansi kreatif. Akuntansi kreatif adalah :
"istilah yang biasanya digunakan oleh pers populer untuk mengacu kepada apa yang dianggap oleh jurnalis dilakukan oleh akuntan, untuk menjadikan laporan keuangan tampak lebih bagus dari yang seharusnya." (Belkaoui, 78:2011).

Di dalam akuntansi kreatif mencakup aktivitas-aktivitas seperti penipuan, pemalsuan, atau penyulapan angka-angka akuntansi. Semua dilakukan dengan melihat celah dari aturan akuntansi. Sabau (2013) berkesimpulan bahwa akuntansi kreatif termasuk dalam tindakan manipulasi keuangan. Hampir senada dengan yang disampaikan oleh Odia dan Ogiedu (2013). Menurut mereka bahwa teknik yang digunakan dalam teknik akuntansi kreatif adalah dengan menyampaikan informasi yang salah kepada pengguna laporan perusahaan melalui laba perusahaan dan struktur modal, sehingga memiliki kecenderungan tindakan penipuan. Untuk menghasilkan laporan keuangan yang sesuai dengan keinginan mereka. (Breton, et.al, Suwardjono, Naser, dan Amat et.al dalam Widarto, 2010). Di Indonesia akuntansi kreatif terjadi pada beberapa perusahaan ternama, di antaranya Bank Century, Bank Duta, Bank Lippo, PT Gas Negara, PT Kimia Farma, kasus PT Citra Marga Nusapala Persada, Merck, serta PT Telkom Universitas Teknologi Sumbawa

(Amrozi, 2008). Tidak hanya erjadi di sektor swasta, di sektor pemerintah juga terjadi kecurangan akuntansi. Dalam laporan Pusat Kajian Anti Korupsi Universitas Gajah Mada (PUKAT UGM), kerugian Negara pada triwulan III 2010 mnencapai angka di bawah Rp 1 miliar dengan 39 kasus. Pada tahun yanng sama Badan usat Statistik (BPS) mencatat angka korupsi bnyak terjadi di daerah pada sector infrastruktur sebesar 38\% jika dibandingkan dengan sector lainnya. Indoesian Corruption Watch (ICW) menyebutkan pada tahun 2013 terjadi kasus korupsi yang marak di Indonesia. Dikonfirmasi dengan hasil pemeriksaan BPK semester I tahun 2013, potensi kerugian Negara mencapai angka Rp 56,98 triliun.

Praktik akuntansi yang terjadi saat ini merupakan akuntansi yang bernuansa kapitalis. Hakikat dari faham kapitalis ialah selalu berupaya untuk menumpuk kekayaan dalam jumlah besar. Kapitalisme merupakan suatu bentuk tatanan ekonomi yang digunakan oleh semua masyarakat di mana sistem ekonominya terintegrasi dengan sistem pasar. Dengan kata lain dapat dikatakan bahwa kapitalisme terbentuk dari pemikiran-pemikiran tentang kepemilikan pribadi, uang, kredit, modal, dan keuntungan. Selanjutnya pemikiran-pemikiran tersebut diinstitusikan, sehingga mereka menjadi bagian dari sistem ekonomi. Motif menumpuk kekayaan dengan menggunakan kesatuan usaha dan tata buku berpasangan sebagai alat. Maka dengan itu akuntansi telah ikut mempengaruhi akal dan hati manusia. Motif menumpuk kekayaan, menjadikan akuntan sebagai pribadi yang kapitalistik.

$$
\begin{aligned}
& \text { “.. bila akuntansi dilahirkan dalam lingkungan yang } \\
& \text { kapitalistik maka informasi yang disampaikan } \\
& \text { mengandung nilai-nilai kapitalistik. Kemudian } \\
& \text { keputusan dan tindakan yang diambil seseorang yang } \\
& \text { berdasarkan pada informasi ini juga mengandung nilai- } \\
& \text { nilai kapitalistik." (Triyuwono, 2012:27). }
\end{aligned}
$$

Dalam sebuah tulisan Max Weber menegaskan :

"Organisasi modern yang rasional dari perusahaan kapitalis tidak akan mungkin terjadi tanpa adanya dua faktor penting di dalam perkembangannya : pemisahan bisnis dari rumah tangga ... dan, berkaitan erat dengannya, pembukuan yang rasional." (Belkaoui,2011:15). 
Niliai-nilai kapitalistik dapat memicu terjadinya kejahatan di dalam profesi akuntan. Kejahatan yang sering terjadi dalam bentuk kecurangan akuntansi. Berikutnya beberapa kasus lain terkait kejahatan akuntansi di Indonesia. Tahun 2001 KAP (Kantor Akuntan Publik) Siddharta Siddharta dan Harsono terbukti menyogok aparat pajak di Indonesia sebesar US\$ 75 ribu. Tahun 2004 terjadi pelanggaran terhadap pelaksanaan audit laporan keuangan PT Muzatek Jaya yang melibatkan KAP (Kantor Akuntan Publik) Drs. Mitra Winata dan rekan, sehingga KAP (Kantor Akuntan Publik) Drs. Mitra Winata dibekukan karena melanggar SPAP (Standar Profesional Akuntan Publik). Kasus Mulyana W Kusuma salah seorang anggota KPU (Komisi Pemilihan Umum) pada tahun 2004 yang telah melakukan penyuapan kepada anggota BPK (Badan Pemeriksa Keuangan) ketika melakukan audit keuangan terhadap pengadaan logistik pemilu. Tahun 2006 kasus PT Kereta Api Indonesia (KAI) laporan keuangannya di tahun tersebut, dilaporkan mendapatkan laba padahal sesungguhnya tengah merugi. Kasus kredit macet di BRI (Bank Rakyat Indonesia) Cabang Jambi pada tahun 2010. Melibatkan seorang akuntan publik yang menyusun laporan keuangan sebuah perusahaan otomotif Raden Motor dengan harapan dapat diberikan pinjaman oleh pihak BRI (Bank Rakyat Indonesia). Terdapat beberapa aktivitas laporan keuangan Raden motor yang tidak dimasukkan ketika mengajukan kredit ke pihak bank. Akhirnya semua proses yang dilakukan tadi berakhir menjadi kredit macet di BRI (Bank Rakyat Indonesia) Cabang Jambi. Tahun 2011 kasus Malinda Dee yang melakukan pembobolan rekening nasabah dengan memalsukan tanda tangan nasabah di dalam formulir transfer. Contoh kasus di atas menunjukkan kepada kita bahwa kasus kejahatan akuntansi terjadi di mana-mana, termasuk di Negara kita Indonesia. Dari uraian latar belakang tersebut kami ingin memahami makna kejahatan akuntansi di Indonesia. Berdasarkan kesadaran dan pengalaman mahasiswa akuntansi UTS.

\section{METODE}

Jenis penelitian ini adalah penelitian kualitatif di mana proses peneltiannya sangat alamiah. Disebut alamiah karena kami sebagai peneliti akan berbaur langsung dengan informan penelitian. Penelitian kualitatif tidak untuk melakukan generalisasi, hasilnya nanti hanya akan berlaku bagi situs di mana penelitian ini dilakukan. Efferin et.al (2004) menyatakan bahwa penelitian kualitatif ini disebut juga sebagai 'penelitian langkah fleksibel'. Moleong (2008) menjelaskan bahwa penelitian kualitatif adalah penelitian yang bermaksud untuk memahami tentang apa yang dialami oleh subyek penelitian (misalnya perilaku, persepsi, motivasi, dan tindakan) secara holistic dan dengan cara deskripsi dalam bentuk kata-kata dan bahasa pada suatu konteks khusus yang alamiah dan dengan memanfaatkan berbagai metode alamiah.

Creswell (2009) menegaskan bahwa studi yang berupaya mengungkap makna tindakan subjektif yang unik atas persepsi dari para individu pelaku, tidak mungkin dicapai jika mengandalakan pendekatan positivisme yang bersifat general. Myers (2009) menyampaikan bahwa penelitian kualitatif dirancang untuk membantu memahami orang dan apa yang mereka perkatakan dan lakukan, sehingga dapat memahami konteks sosial budaya dengan lebih mendalam di mana orang tersebut hidup.

Pendekatan penlitian ini menggunakan studi fenomenologi. Menggunakan pendekatan ini karena kami ingin menggali data dari pengalaman para informan, lalu seperti apa meraka memahami pengalaman mereka sendiri. Dalam konteks ini kami akan mengkaji pemahaman dari apa yang dialami oleh mahasiswa akuntansi Universitas Teknologi Sumbawa (UTS) sebagai pengalaman mereka. Khususnya pengalaman selama belajar akuntansi di program studi akuntansi Universitas Teknologi Sumbawa. Fatchan (2013) berargumen bahwa dalam penelitian kualitatif, fenomenologi merupakan salah satu pendekatan dengan ttik tumpu penggalian data atau informasi berupa tindakan para pelaku fenomena dengan tujuan memahami respon atas keberadaan individu manusia dalam suatu pengalaman yang dipahaminya dalam berinteraksi. 
Daymon dan Holloway (2008:231) menjelaskan bahwa inti dari riset fenomenologi adalah gagasan yang berhubungan dengan realitas kehidupan masing-masing individu yang berbeda melalui perspektif bersama, sehingga tugas peneliti untuk mengakses pemikiran akal sehat orang-orang dengan tujuan menafsirkan, motifmotif, tindakan dan dunia sosial dari sudut pandang individu. Fenomenologi dapat dikatakan sebagai pertemuan antara kejadian dan kesadaran.

Teknik pengupulan data yang akan kami lakukan dengan wawancara, observasi, dokumentasi dan triangulasi. Wawancara yang akan kami lakukan adalah wawancara mendalam dan tidak terstruktur dengan infroman, yakni mahasiswa akuntansi Universitas Teknologi Sumbawa. Wawancara mendalam yang kami lakukan nanti pastinya akan sangat terkait dengan kajian penelitian ini.

Teknik observasi dapat kami lakukan dengan mengamati bagaimana mahasiswa berpendapat di dalam kelas ketika proses belajar mengajar secara langsung. Hasil observasi di kelas ini nanti akan kami komparasikan dengan hasil wawancara yang kami lakukan nantinya di luar kelas. Apakah itu di halaman kampus, di kediaman mahasiswa, maupun tempat mereka sering berkumpul dan belajar bersama. Teknik observasi yang kami lakukan adalah observasi berperan serta ketika bersama berada di kelas pada proses belajar mengajar serta observasi tidak berperan serta ketika mahasiswa berada di luar kelas.

Teknik dokumentasi yang kami maksudkan di sini dengan berusaha memperoleh data, catatan, maupun gambar yang menerangkan tentang kajian penelitian yang kami lakukan ini. Terakhir teknik triangulasi, terdiri dari triangulasi sumber, teknik, dan waktu. Triangulasi sumber maksudnya dengan melakukan wawancara kepada beberapa informan dengan topik pertanyaan yang sama ke tiap-tiap informan. Triangulasi teknik, dengan membandingkan hasil dari teknik-teknik yang berbeda untuk kajian yang sama. Membandingkan hasil wawancara, observasi, dan dokumentasi. Triangulasi waktu akan kami lakukan dengan menemui seluruh informan untuk berdiskusi dalam minimal tiga kesempatan waktu yang berbeda.

Terdapat tiga tahapan analisa data yang akan kami lakukan dalam penelitian fenomenologi. Tahap pertama kajian yang akan kami lakukan adalah kajian dengan menggabungkan antara obyek yang dipersepsikan (noema) dan pemahaman subjektif (noesis) terkait suburnya kasus kejahatan akuntansi di Indonesia. Tahap kedua kami akan melewati tahapan epoche. Pransejit (2002) mejelaskan bahwa epoche merupakan prosedur atau perilaku peneliti yang digunakan dalam bentuk pertanyaan yang harus dimunculkan yang berkaitan dengan masalah metafisika yang sebenarnya terkait daam mental individu. Hasil dari kajian noema, noesis, dan epoche disebut dengan analisis intensionalitas. Tahap ke tiga adalah eidetic reduction. Dalam tahapan ini kami akan menguraikan dan menugngkapkan realitas yang diperoleh dalam tahapan epoche sebelumnya.

\section{HASIL DAN PEMBAHASAN}

Informan pertama bernama Amri menyatakan :

"Saya tahu sih, pak. Kalau yang namanya kejahatan

akuntansi itu ada di dalam akuntansi." (noema)

Seperti itulah Amri menyampaikan kepada kami. Amri mengetahui bahwa kejahatan akuntansi terjadi. Amri kembali menjawab pertanyaan kami tentang contoh kejahatan akuntansi yang dipahami.

"Kejahatan akuntansi itu, biasanya itu ..eee... seperti

pemalsuan pencatatan gitu, itu biasanya. Biasa kalau

ndak itu biasanya pajak biasanya." (epoche)

"Seperti kasus Gayus di TV itu, pak." (noesis)

Adanya kejahatan akuntansi mengindikasikan bahwa terdapat kesalahan di dalam ilmu akuntansi. Kami berusaha menggali pemahaman Amri secara lebih mendalam lagi. Amri dengan spontan bereaksi menjawab :

"Bukan, bukan sih dia ilmu itu yang salah, pak. Tapi orangnya itu yang salah, pak. Itu kembali ke diri sendiri 
itu, pak. Ee.. bagaimana memberlakukan ..ee apa ee dirinya itu. Apakah apa istilahnya ne. apakah dimanfaatkan dengan baik atau tidak. Kembali ke diri sendiri sebenarnya."

Intentional analysis dari Amri menjelaskan bahwa dengan Amri menyaksikan kasus Gayus di televisi, telah memberikan sebuah pengalaman dan kesadaran. Bahwa kasus kejahatan akuntansi di Indonesia itu ada dan terjadi. Amri memiliki pengalaman dan kesadaran tentang adanya kasus kejahatan akuntansi di Indonesia. Pengalaman tersebut muncul pada saat Amri menyaksikan berita tentang Gayus Tambunan sang mafia pajak di televisi. Dari pengalaman itu memunculkan kesadaran Amri tentang adanya kasus kejahatan akuntansi di Indonesia. Dari kutipan-kutipan hasil wawancara dengan Amri, kami menyampaikan eidetic reduction. Eidetic reduction dalam analisa fenomenologi terhadap Amri, bahwa kejahatan akuntansi terjadi bukan karena ilmu akuntansinya yang salah, tetapi tergantung kepada pelaku akuntansi itu sendiri.

Informan ke dua bernama Arief. Ketika kami melontarkan pernyataan bahwa akuntansi itu memiliki sisi jahat. Arief langsung menyela dengan semangat :

"Ooo... sangat-sangat jahat (noema). Banyak pemalsuan pencatatan keuangan, pak (epoche). Saya saat ini juga bekerja malam di kantin rumah sakit atas itu, pak. Sampai jam tujuh pagi. Karena menurut saya ketika seperti ini, ee di pembukuan itu bisa saja saya sebagai orang yang dipekerjakan di sana. Seperti ini...orang belanja, ketika mereka belanja saya bisa saja ketika ada niat itu, saya memalsukan bukunya. Saya palsukan pembukuannya. Dalam artian ketika orang membeli sesuatu barang, saya bisa saja memalsukan yaitu dalam artian saya tidak mencatatnya (noesis).

Kondisi ini menjadikan dunia pendidikan harus mengambil peran. Peran yang dapat menekan angka kasus kejahatan akuntansi itu sendiri. Arief menjawab :

"Menurut saya sih, secara umum kurikulum yang kita pelajari tidak ada yang dikurangkan, seperti itu. Mungkin kalaupun ada yang ditambahkan itu ya nilai-nilai moralnya perihal moralnya untuk mahasiswa, mmm...seperti itu. Karena menurut saya tiap bidang apa pun itu memiliki celah tersendiri untuk melakukan kejahatan. Baik itu akuntansi, manajemen, sektor yang teknik. Seperti teknik yang ada di UTS itu sendiri. Jadi lebih ke mental dan moral aja sih. Setidaknya para pengajar itu harus memberi teguran,..seperti itu. Terus setidaknya sebelum kuliah itu ada...ada...bukan seperti ceramah sih. Tapi mengajak mahasiswa itu untuk berlaku lenih baik...seperti itu."

Untuk hasil wawancara bersama Arief, kami mendapatkan intentional analysis berikut ini. Bahwa Arief sangat sadar betul terhadap kasus kejahatan akuntansi. Arief mendapatkan kesadaran ini secara kuat, karena dia secara langsung bekerja sebagai penjaga kantin salah satu rumah sakit di Sumbawa. Bekerja di rumah sakit dapat dkategorikan sebagai pengalaman. Eidetic reduction bersama Arief, kami berpendapat bahwa untuk menekan angka kasus kejahatan akuntansi, para pengajar lebih menanamkan nilai-nilai moral kepada para mahasiswanya.

Informan ke tiga bernama Ayu. Ayu memberikan komentar terhadap kasus kejahatan akuntansi.

"Sepertinya ada, pak (noema). Eee...soalnya kan waktu itu ee... kebetulan ayah saya itu di..bekerja di inspektorat. Jadi sering menangani banyak kasus atau apa...seperti itu (epoche). Jadi karena eeee dii eee jadii apa ya? saya melihat 
semua-muanya itu. Kasus-kasus yang sudah ayah periksa itu dan dengar itu waktu ada teman-temannya datang itu. Saya mendengar percakapan itu seperti agka-angka itu semuanya dirubah seperti itu, pak. Jadinya ndak sesuai antara realita dengan apa yang ada di eee laporannya seperti itu..berbeda gitu pak. Jadinya kayak ada perbedaan gitu pak." (noesis).

Apakah akuntansi patut disalahkan dalam kasus kejahatan akuntansi ini ? Ayu menjawab :

"Kalau menurut saya sih kayaknya nggak deh pak. Dari diri sendirinya itu. Jadi dia nggak menerapkan apa yang sudah dia pelajari gitu. Dia hanya mementingkan egonya sendiri untuk mendapatkan keuntungan seperti apa yang dia mau, kayak gitu pak. Jadi menurut saya nggak ada kesalahan di akuntansi itu. Dia menyalahgunakan apa yang sudah dia dapatkan. Gitu nah pak, maksudnya."

Dalam percakapan Ayu, bahwa intentional analysis menjelaskan Ayu meyakini adanya kejahatan akuntansi. Pengalaman dan kesadarannya bersumber dari apa yang sering dilakukan ayahnya. Di mana ayahnya adalah pegawai kantor inspektorat di Kabupaten Sumbawa. Eidetic reduction yang dapat kami sampaikan di sini bahwa kejahatan akuntansi itu sangat tergantung dari diri sendiri (akuntan itu sendiri).

Informan ke empat sorang mahasiswa bernama Nisa. Apakah Nisa pernah dengar bahwa banyak kasus kejahatan akuntansi ?

"Banyak terjadi di Indonesia sekarang (noema). Seperti korupsi (epoche) yang sering diberitakan di media, pak (noesis). Salahnya itu kemungkinan pada diri kita sendiri. Mmm..kembali ke moral manusia itu sendiri. Bagaimana $\mathrm{mmm}$ membangun kepercayaannya dia untuk tidak melakukan eee, seperti korup atau manipulatif yang merugikan suatu Negara."

Dari wawancara bersama Nisa kami berhasil menghimpun hal-hal penting sesuai dengan tujuan penelitian. Nisa menyadari adanya banyak kejahatan akuntansi di Indonesia. Terbukti dengan pemberitaan tentang korupsi di berbagai media massa sebagai pengalamannya (intentional analysis). Kami menyimpulkan (eidetic reduction) bahwa kejahatan akuntansi itu kembali kepada moral manusia itu sendiri.

Informan ke lima mahasiswa bernama Faizah. Menurut Faizah tentang kejahatan akuntansi :

"Tahu, pak (noema). Misal korupsi (epoche). Kan sering ditayangkan di berita-berita itu, pak (noesis)"

Lebih lanjut Faizah mengatakan, setelah kami menanyakan kaitan korupsi dengan ilmu akuntansi :

"Itu semua tergantung kepada sosok pribadi sih, pak. Kalau akuntansi itu kan pengetahuan. Nah, bagaimana kita menjaga pengetahuan kita itu tergantung sama diri kita sendiri sih. Sebab itu pertanggungjawaban kita ke publik."

Faizah mengetahui adanya kejahatan akuntansi. Faizah mengetahui dari pengalamannya menyaksikan berita-berita korupsi di televisi (intentional analysis). Jadi kejahatan akuntansi itu kembali ke pribadi kita masing-masing (eidetic reduction).

Informan ke enam bernama Rizky, kami bertanya kepada Rizky tentang kasus kejahatan akuntansi. Rizky menjawab :

"Kalau kasus memang ada sih (noema). Seperti kasus perpajakan yang dilakukan Gayus. (epoche) di berita. Menghilangkan informasi yang ada, atau menambahkan informasi yang tidak ada. Akibatnya informasi itu simpang 
siur. Merugikan orang yang membutuhkan informasi itu." (noesis).

Kami mencoba meminta Rizky untuk menjelaskan kaitan akuntansi dengan kejahatan yang terjadi. Rizky menjawab :

"Kalau menurut pendapat saya, pak. Bahwa semua teori itu dicoba dulu. Mungkin saat ini sempurna, mungkin sepuluh tahun ke depan tidak lagi sempurna. Maka akuntansi itu harus punya terobosan-terobosan. Akuntansi itu seperti hanya milik sekelompok orang. Tidak semua masyarakat mengerti akuntansi. Perlu sebuah pembelajaran agar semua orang mengerti akuntansi. "

Kami kembali meminta Rizky menjelaskan kasus Gayus

"Sebenarnya tergantung manusianya pak. Meskipun secara materi ilmu telah dibekali dengan hal-hal yang baik."

Rizky menyadari adanya kejahatan akuntansi di Indonesia. Kasus Gayus Tambunan pernah diketahuinya melalui media televisi. Hal tersebut dapat menjadi satu pengalaman tersendiri buat Rizky (intentional analysis). Dalam hal ini kami menyimpulkan (eidetic reduction) bahwa kejahatan akuntansi terjadi tergantung kepada manusia itu sendiri.

Informan ke tujuh bernama Varadika. Seperti informan-informan sebelumnya, kami meminta Varadika untuk menjelaskan tentang kejahatan akuntansi di Indonesia.

"Pernah dengar sih, pak (noema). Kayak yang korupsi itu

melakukan kesalahan atau manipulasi gitu pak (epoche).

Banyak saya lihat di TV pak, kalau kasus-kasus korupsi

itu."(noesis)

Kami kembali meminta Varadika menjelaskan hubungan ilmu akuntansi dengan kejahatan akuntansi yang ada.

"Mmm.. seperti dari orang-orangnya pak. Cara mereka menerapkannya. Bukan dari ilmunya yang salah. Kembali ke orang masing-masing dengan tujuan masingmasing,pak."

Varadika memiliki pengalaman dan kesadaran tentang kasus kejahatan akuntansi di Indonesia. Secara sadar Varadika pernah mendengarkan tentang kejahatan akuntansi. Secara pengalaman Varadika mengikuti pemberitaan tentang korupsi melalui media televisi (intentional analysis). Bahwa kejahatan akuntansi terjadi tergantung dari manusianya, bukan karena kesalahan ilmu akuntansi yang dipraktikkannya (eidetic reduction).

Informan ke delapan adalah Wahyu. Berikut beberapa kutipan wawancaranya terkait dengan kejahatan akuntansi di Indonesia :

"Pernah dengar dan baca dalam beberapa buku dan bahan ajar, pak (noema). Contohnya pembukuan palsu (epoche). Misalnya perusahan go public banyak membuat pembukuan palsu untuk menarik minat investor untuk membeli saham meraka, pak." (noesis).

Berikut ini tanggapan Wahyu ketika kami meminta untuk menjelaskan hubungan akuntansi dengan kejahatan yang terjadi.

"Sebenarnya bukan akuntansi-nya sih yang keliru, pak.

Itu lebih kepada sifat dan perilaku akuntan-nya sendiri, pak. Karena tidak beretika sesuai dengan etika profesinya sebagai seorang akuntan. Seharusnya mampu melaporkan akuntansi secara independen tanpa intimidasi dari pihak manapun."

Wahyu memiliki pengalaman dan kesadaran tentang kejahatan akuntansi di Indonesia. Kesadaran dan pengalamannya muncul dari berbagai buku dan bahan ajar yang pernah dibaca dan dipelajarinya (intentional analysis). Terkait dengan kejahatan akuntansi yang 
terjadi. Wahyu menjelaskan bahwa bukan akuntansi yang keliru. Lebih kepada sifat dan perilaku akuntan itu sendiri (eidetic reduction)

Informan ke sembilan bernama Nurida sebagai informan terakhir dalam penelitian ini. Kami memintanya berkomentar tentang pemahamannya. Pemahaman berupa kesadaran dan pengalamannya erkait dengan kejahatan akuntansi.

"Mmmm....tahu sih, pak (noema). Korupsi misalnya, pak. Banyak di Indonesia (epoche). Hampir setiap waktu keluar di tv, pak.." (noesis)

Menurut Nurida setelah kami meminta menjelaskan keterkaitan akuntansi dengan korupsi :

"Eee sejauh ini yang saya tahu kalau misalkan ada korupsi itu di perhitungannya, pak. Biasanya kalau ada yang bilang saya nggak ambil uang itu, tapi saya salah mencatatnya, gitu. Manusianya salah karena tidak teliti. Untuk meminimalisir hal itu, sebaiknya mencari tenaga yang profesional. Tenaga yang memang teliti, tekun, ulet di bidang akuntansi itu, pak. “

Intentional analysis yang dapat kami sampaikan di sini ialah Nurida memiliki kesadaran dan pengalaman tentang kejahatan akuntansi di Indonesia. Dengan sering melihat pemberitaan di televisi, secara langsung itu menjadi pengalaman yang menumbuhkan kesadarannya. Untuk eidetic reduction sesuai dengan hasil wawancara bersama Nurida. Kami berkesimpulan bahwa kejahatan akuntansi itu terjadi dikarenakan oleh faktor manusia yang tidak teliti, tidak tekun, dan tidak ulet di bidang akuntansi.

Secara keseluruhan informan memiliki kesadaran dan pengalaman tentang kasus kejahatan akuntansi di Indonesia. Kesadaran dan pengalaman informan didapatkan dari sumber dan cara yang berbeda. Ada pula kesadaran pengalaman yang didapatkan dari sumber yang sama. Secara dominan para informan kesadaran dan pengalamannya didapatkan dari berita-berita di media massa. Tercatat tiga informan yang secara khusus mendapatkan melalui cara dan tempat yang masing-masing berbeda. Seperti Arief seorang mahasiswa yang kuliah sambil bekerja di kantin salah satu rumah sakit. Menurutnya bahwa di dalam pekerjaan yang dilakukan, ada celah untuk melakukan kejahatan akuntansi. Misalnya dengan tidak mencatat nama dan jumlah barang yang terjual pada saat Arief bertugas di kantin tersebut. Lebih lanjut lagi Arief memiliki harapan agar para pengajar akuntansi dapat menanamkan nilai-nilai moral kepada mahasiswanya di sela-sela perkuliahan berlangsung. Informan Ayu juga mendapatkan kesadaran dan pengalaman tentang kasus kejahatan akuntansi dari sumber yang berbeda dengan Arief. Ayu menyadari dan mengalami sendiri dengan melihat dan mendengar dari percakapan ayahnya. Di mana Sang Ayah merupakan salah satu pegawai inspektorat kabupaten Sumbawa. Ayu menuturkan bahwa dari laporan yang diperiksa ayahnya, banyak angka-angka yang dirubah sehingga tidak sesuai dengan yang sebenarnya. Kejahatan-kejahatan akuntansi itu kembali ke diri kita masingmasing, bukan karena ilmu akuntansi yang salah. Informan Ayu mengakhiri penjelasannya. Berbeda lagi dengan hasil yang kami dapatkandari informan Wahyu. Wahyu memperoleh pengalaman dan kesadaran tentang kasus kejahatan akuntansi dari berbagai buku dan bahan ajar yang pernah dibacanya. Menurut Wahyu kasus ini banyak terjadi di perusahaan-perusahaan go public. Mereka perusahaan-perusahaan go public banyak membuat pembukuan palsu. Ini dilakukan agar para investor tertarik untuk membeli saham perusahaan mereka. Enam informan lainnya memiliki jawaban serupa. Mereka mendapatkan kesadaran dan pengalaman tentang kasus kejahatan akuntansi darisiaran berita di media massa. Baik itu dari media cetak maupun media elektronik. Seperti yang disampaikann oleh informan Amri, Nisa, Faizah, Rizky, Varadika, dan Nurida.

Ada yang menarik di dalam temuan penelitian ini. Ketika kami meminta informan untuk mengkaitkan antara kasus kejahatan akuntansi dengan ilmu akuntansi itu sendiri. Semua informan hampir memiliki jawaban yang sama. Informan Amri mengatakan bahwa bukan ilmu itu yang salah, tapi orangnya yang salah. Itu kembali ke diri sendiri, apakah ilmunya dimanfaatkan dengan baik atau tidak. Kalau menurut Arief, 
bahwa tiap bidang apa pun memiliki celah untuk melakukan kejahatan. Lebih diutamakan perbaikan mental dan moral mahasiswa, agar dapat berlaku lebih baik. Demikian juga informan Ayu mengatakan bahwa ilmu akuntansi itu tidak salah. Kembali ke diri manusianya yang tidak menerapkan apa yang sudah dia pelajari. Hanya mementingkan ego untuk mendapatkan keuntungan semata. Sama halnya dengan jawaban informan Nisa. Bahwa kejahatan akuntansi itu tergantung kepada moral manusia itu sendiri. Bagaimana dia membangun kepercayaan dirinya untuk tidak korup dan manipulative sehingga merugikan Negara. Faizah menyampaikan kepada kami terkait hubungan akuntansi dengan kejahatannya. Bahwa akuntansi itu adalah pengetahuan yang harus dipertanggungjawabkan. Soal kejahatan sangat tergantung kepada pribadi manusianya sendiri. Selanjutnya Rizky berpendapat bahwa kejahatan akuntansi itu sangat tergantung manusianya. Meskipun manusia tersebut telah dibekali dengan hal-hal yang baik. Informan Varadika menjelaskan bahwa bukan ilmu akuntansi yang salah. Kembali ke manusianya dengan tujuan masing-masing. Informan Wahyu menambahkan bukan akuntansi yang keliru. Lebih kepada sifat dan perilaku akuntan yang tidak beretika. Terakhir Nurida sedikit berbeda penjelasannya. Namun masih dalam konteks yang sama bahwa aspek manusia menjadi yang utama dalam penerapan ilmu akuntansi.

\section{SIMPULAN}

Berbagai rangkaian proses penelitian ini telah kami lakukan. Tiba saatnya untuk memberikan kesimpulan akhir. Dengan berdasar kepada seluruh hasil wawancara bersama informan. Merujuk dari hasil dan pembahasan pada bagian sebelumnya dari tulisan ini. Seluruh informan menekankan bahwa aspek manusia memegang peranan penting bagi terjadinya kasus kejahatan akuntansi di Indonesia. Baik manusia itu sebagai seorang mahasiswa akuntansi maupun manusia yang berprofesi sebagai seorang akuntan. Profesi akuntan yang dimaksudkan di sini dapat diurai menjadi beberapa profesi, yakni akuntan pendidik, akuntan perusahaan, akuntan pemerintah, dan akuntan publik. Menyimak salah satu kasus dari penuturan informan, misalnya kasus Arief. Arief selain sebagai seorang mahasiswa, dapat diasumsikan Arief juga berprofesi sebagai akuntan perusahaan. Di mana dia bertugas sebagai penjaga kantin rumah sakit. Tugasnya mencatat semua pemasukan dan pengeluaran yang terjadi atas barang dagangan di kantin. Tentunya Arief mengetahui lebih banyak tentang kondisi transaksi yang terjadi di kantin tersebut. Agency theory telah menjelaskan tentang adanya asimetri informasi yang dimiliki antara agen dan prinsipal. Agen memiliki informasi yang lebih memadai dibandingkan dengan informasi yang dimiliki oleh prinsipal. Ketika agen memiliki informasi yang lebih, maka ada peluang terjadinya moral hazard di dalamnya. Teori tersebut berlaku pada kasus yang disampaikan oleh Arief.

Mencermati penegasan oleh informan lain di dalam penelitian ini. Seperti yang disampaikan oleh Ayu. Kejahatan akuntansi terjadi disebabkan karena ego seseorang untuk mendapatkan keuntungan bagi dirinya sendiri. Dihubungkan dengan kasus Arief, meski agen memiliki informasi yang lebih memadai dibandingkan dengan prisipal. Jika ego seorang prinsipal bisa dikendalikan, maka kejahatan akuntansi tidak akan terjadi. Informan Rizky, Faizah, Varadika, Nurida, dan Amri juga menyampaikan hal yang tidak kalah pentingnya. Menurutnya meskipun manusia itu telah dibekalkan dengan hal-hal baik, manusia itu sendiri yang akan menentukan langkahnya sendiri. Informan Nisa menjelaskan bahwa kejahatan akuntansi lebih pada sisi moral manusianya.

Di bagian akhir ini kami ingin lebih mengkerucutkan penjelasan di atas. Seluruh infroman berpendapat bahwa aspek manusia sangat menentukan bagi terjadinya kasus kejahatan akuntansi di Indonesia. Menggarisbawahi aspek manusianya, kemudian kami berusaha mencari irisan-irisan dari kutipan wawancara mereka. Kasus Arief beririsan dengan celah terjadinya moral hazard. Kasus Rizky, Faizah, Varadika, Nurida, dan Amri beririsan kepada baik buruk manusia. Kasus Nisa lebih tegas menyentuh irisan ke arah moral manusia. Artinya ketiga irisan ini (moral hazard, baik buruk manusia, moral) memberikan penegasan kepada satu hal. Bahwa 
ada bagian dari aspek manusia yang perlu menjadi perhatian kita semua, yakni aspek moral. Dengan kata lain ketiga irisan di atas jika digabungkan akan terwakilkan menjadi satu nilai yakni moral.

Selain itu menurut kami terdapat temuan menarik lain di dalam penelitian ini. Hal menarik tersebut ialah seluruh informan menyampaikan tentang ilmu akuntansi yang tidak dapat disalahkan dalam konteks ini. Walaupun akuntansi tidak dapat disalahkan, akan tetapi hanya orang-orang yang memahami akuntansi yang dapat menemukan celah kejahatan akuntansi. Dengan kewenangan yang dimiliki, manajer bisa bertindak dengan hanya menguntungkan dirinya sendiri dan mengorbankan kepentingan para pemegang saham. Sebagaimana dijelaskan juga di dalam agency theory di atas.

Akhirnya kami berkesimpulan bahwa makna kasus kejahatan akuntansi di Indonesia ditentukan oleh dua faktor utama yakni ilmu akuntansi dan moral manusia itu sendiri. Dewi (2016) menyebutkan bahwa terdapat perbedaan kecenderungan melakukan kecurangan akuntansi antara individu yang memiliki level penalaran moral rendah dan level penalaran moral tinggi. Nilai-nilai dan moral pribadi perorangan dan konteks sosial yang menentukan apakah suatu perilaku tertentu dianggap sebagai perilaku etis dan perilaku tidak etis. (Adelin, Fauzihardani, 2013). Sebagai sebuah sintesa dari penelitin ini kami menyebutkannya menjadi accounting is amor, amor dapat berarti cinta. Amor juga dapat berarti akuntansi dan moral. Maka dari itu berakuntansilah dengan cinta. Bagaimana bentuknya? Ketika berakuntansi, sandingkanlah akuntansi itu dengan moral agar kejahatan itu menjadi tiada karenanya.

\section{DAFTAR PUSTAKA}

Adekin, V., Fauzihardani, E. (2013). Pengaruh Pengendalian Internal, Ketaatan Pada Aturan Akuntansi dan Kecenderungan Terhadap Perilaku Tidak Etis. Wahana Riset Akuntansi. Vol 1.No 2. 259-276.

Amrozi, M.F. (2008). Creative Accounting, Working Paper Seminar Akuntansi Keperilakuan. Program Pascasarjana, Program Doktor Ilmu Akuntansi. Universitas Airlangga.

Belkaoui, A. R. (2011). Accounting Theory Teori Akuntansi. Jakarta Selatan: Salemba Empat.

Cresswell, J. (2009). Research Design Pendekatan Kualitatif, Kuantitaif, dan Mix. Yogyakarta: Pustaka Pelajar.

Daymon, C. d. (2008). Riset Kualitatif Dalam Public Relations dan Marketing Comunications. Yogyakarta: Penerbit Bentang.

Dewi, GAKRS. (2016). Pengaruh Moralitas Individu dan Pegendalian Internal pada Kecurangan Akuntansi. Jurnal Ilmiah Akuntansi. vol 1. No 1. 77-92.

Efferin et.al,. (2004). Metode Penelitian Untuk Akuntansi. Sebuah Pendekatan Praktisi. Malang: Bayu Media.

Fatchan. (2013). Penelitian Kualitatif, !O Langkah Penelitian Kualitatif Pendekatan Konstruksi dan Fenomenologi. Malang: UM PRESS.

Gaffikin, M. (1991). Redefining Acounting Theory. Jakarta.

Irianto,G., Novianti, N., Wulandari, P.P. 2014. "Kamuflase" Dalam Praktik Rotasi Auditor. JAMAL Vol 5. No 3393-408.

L.J, M. (2008). Metodologi Penelitian Kualitatif. Bandung: Remaja Rosdakarya.

MD, M. (2009). Qualitative Resarch in Bussines and Management. London: Sage Publication.

Michigan Law Review, B. 6. (n.d.).

Mulia, A.S. (2012). Mengungkap Pemahaman Tentang Akuntansi dari Kecerdasan Emosional, Spiritual dan Sosial Mahasiswa. JAMAL. Vol 3. No 3. 441-456. 
Odia, J.O., Ogiedu, K.O. (2013). Corporate Governance, Regulatory Agency, and Creative Accounting in Nigeria. Mediterranean Journal of Social Science. Vol 4. No 3. 55-66.

Puspasari, N. (2016). Pengaruh Moralitas Individu dan Pengendalian Internal terhadap Kecenderungan Kecurangan Akuntansi : Studi Eksperimen pada Kontek Pemerintah Daerah. Ekuitas Jurnal Ekonomi dan Keuangan. Vol 16. No 2. 130.

Risela, D.A. (2017). Pengaruh IQ, EQ, dan SQ Terhadap Persepsi Etis Mahasiswa Mengenai Akuntansi Kreatif. Jurnal Nominal. Vol VI. No 1.50-65.

Sabau, L.L. (2013). Creative Accounting - The Results of Pressures from Users. west University of Tmisiora, Romania. 636-661.

Schrag, C. O. (1986). Communicative Praxis and The Space of Subjectivity. Indiana: University Press.

Suriasumantri, J. (1998). Filsafat Ilmu : Sebuah Pengantar Populer. Jakarta: Pustaka Sinar Harapan.

Suwardjono. (2011). Teori Akuntansi Perekayasaan Pelaporan Keuangan. Yogyakarta: BPFE Yogyakarta.

Triyuwono, I. (2012). Akuntansi Syariah, Perspektif, Metodologi, dan Teori. Depok: PT Rajagrafindo Persada.

Widarto, (2010). Analis Praktek Akuntansi Kreatif Dalam Konteks Budaya Organisasi PT Bumi dan Pandangan Islam (Khususnya Jaran Amanah) Dalam Menyikapi Praktek Tersebut. WACANA. Vol 13. No 3. 458-465. 